\title{
A painful toe: botfly myiasis
}

\section{Sophie Kay, David Butt, Surjit Lidder, Stephen James}

Department of Trauma \& Orthopaedics, Eastbourne District General Hospital, Eastbourne, UK

\section{Correspondence to} Dr Sophie Kay, sophie.kay2@nhs.net
To cite: Kay $S$, Butt $D$, Lidder S, et al. BMJ Case Rep Published online: [please include Day Month Year] doi:10.1136/bcr-2013201860

\section{DESCRIPTION}

A 47-year-old woman presented with a 2-week history of severe sporadic shooting pain in her right second toe following return from a bird watching holiday in Panama.

On examination she was systemically well. Examination of her right foot revealed a small nonhealing puncture type wound $(1 \mathrm{~mm}$; figure 1$)$ on the plantar aspect of the toe with continual serousanginous discharge. A small white foreign body could be visualised deep in the puncture wound (figure 2).

Surgical exploration under local anaesthesia revealed a large parasite $(0.5 \mathrm{~cm}$; figure 3$)$ subsequently identified as Dermatobia hominis larvae (botfly). Damage to her digital nerve and some pulp loss was observed. The pain completely resolved postprocedure and the recovery has been uneventful.

The botfly is native to Central and South America; all documented cases of $D$ hominis myiasis had recently been to the region. ${ }^{1}$

Larvae transmission occurs by phoresy, with blood-feeding arthropods, such as mosquitos, acting as vectors. Eggs hatch on feeding, stimulated by the warmth of the blood, and enter the skin through the bite puncture. ${ }^{12}$

The larvae are known to infest the subcutaneous skin layer of mammals, often resulting in painful secretory pustules, with a characteristic central pore that provides air to the larvae. They are not known

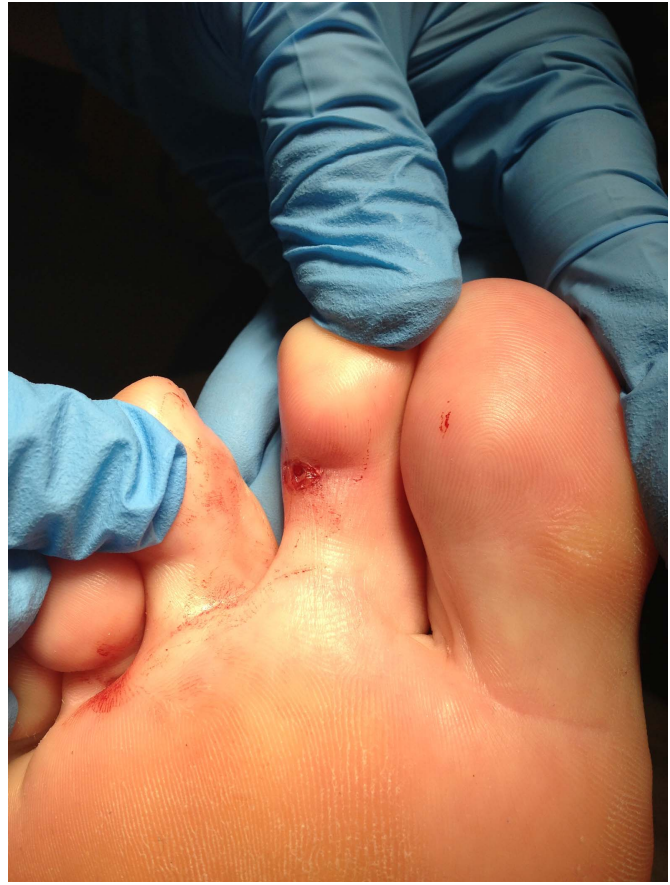

Figure 1 Small puncture-type wound in toe.

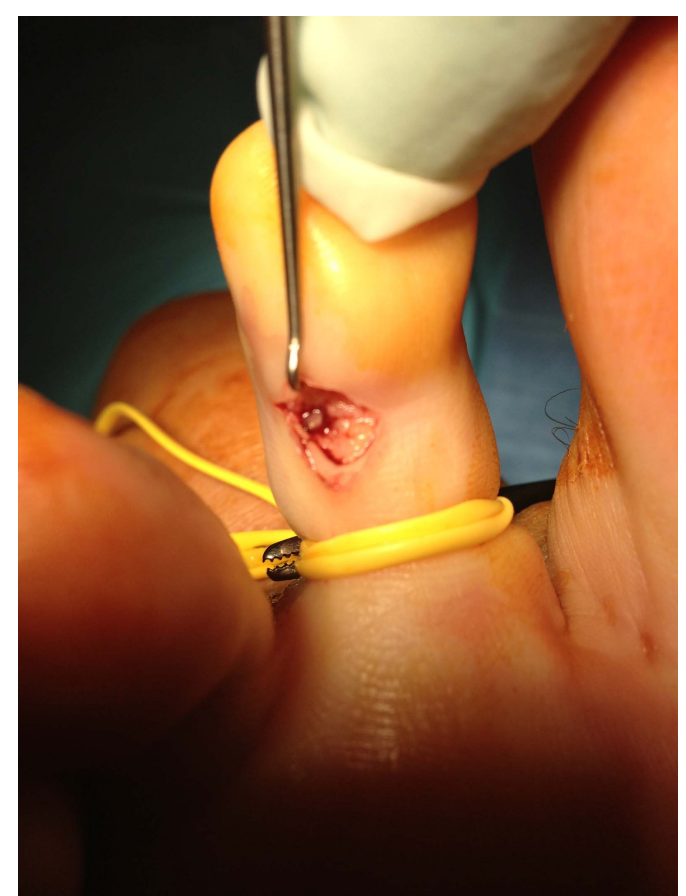

Figure 2 Wound during exploration. A small white foreign body can be seen in the center of the puncture.

to transmit pathogens, and following extraction the wound tends to heal quickly and without complication. $^{12}$

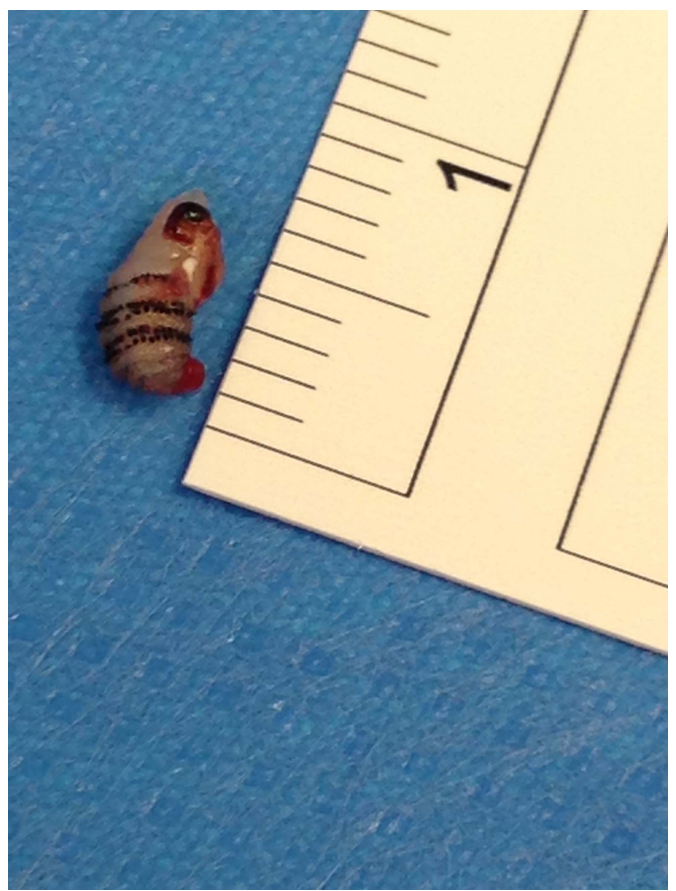

Figure 3 Parasite removed from toe measuring $0.5 \mathrm{~cm}$. Subsequently identified as botfly larva. 


\section{Learning points}

- Differential diagnoses for a puncture wound such as this include penetrating trauma, foreign body, infected insect bite, abscess or sebaceous cyst. Parasitic infestation should be included in the differential diagnosis of a new skin lesion in patients who have travelled to endemic areas. ${ }^{2}$

- The presence of the botfly is not in itself harmful as they are not known to transmit pathogens and the secretions are neutral. ${ }^{2}$ It is the resultant pain and tissue damage which is problematic.

- Management options for myiasis include conservative management, allowing the larvae to exit as per its life cycle, techniques which encourage the larvae to come out by excluding the pore using petroleum jelly/wax, or mechanical extraction using tweezers/venom extractor. Anecdotally surgical extraction is favoured by patients due to quick removal and debridement. ${ }^{12}$
Contributors The patient was under the care of $\mathrm{SJ}$. The case was seen and treated by DB and SL both of whom provided images. The case report was written by SK and edited by DB.

Competing interests None.

Patient consent Obtained.

Provenance and peer review Not commissioned; externally peer reviewed.

\section{REFERENCES}

1 Featured Creatures; Common name human botfly. [Internet source] University of Florida Entomology and Nematology. July 2008. http://entnemdept.ufl.edu/creatures/ misc/flies/human_bot_fly.htm

2 Ofordeme KG, Papa L, Brennan DF. Botfly myiasis: a case report. CJEM 2007:9:380-2.

Copyright 2013 BMJ Publishing Group. All rights reserved. For permission to reuse any of this content visit http://group.bmj.com/group/rights-licensing/permissions.

BMJ Case Report Fellows may re-use this article for personal use and teaching without any further permission.

Become a Fellow of BMJ Case Reports today and you can:

- Submit as many cases as you like

- Enjoy fast sympathetic peer review and rapid publication of accepted articles

- Access all the published articles

- Re-use any of the published material for personal use and teaching without further permission

For information on Institutional Fellowships contact consortiasales@bmjgroup.com

Visit casereports.bmj.com for more articles like this and to become a Fellow 